Article

\title{
Strategies, Processes, and Results for the Future Water Supply of the Växjö Municipality: Evaluation of an Evidence-Based Case Study of Long-Term Strategies within the Water and Wastewater Sector in Sweden
}

\author{
Nasik Najar ${ }^{1, *(1)}$ and Kenneth M Persson ${ }^{2}$ \\ 1 Department of Construction Engineering and Lighting Science, School of Engineering, Jönköping University, \\ 55111 Jönköping, Sweden \\ 2 Division of Water Resources Engineering, Lund University, Box 118, S-221 00 Lund, Sweden; \\ kenneth_m.persson@tvrl.lth.se \\ * Correspondence: nasik.najar@ju.se; Tel.: +46-736-556-581
}

Received: 10 July 2019; Accepted: 8 October 2019; Published: 16 October 2019

\begin{abstract}
In 2009, the Bergaåsen Water Supply Scheme was put into operation to ensure the future drinking water supply of two municipalities in southern Sweden. Bergaåsen replaced two vulnerable water treatment plants. It was implemented in an environment that was characterized by sensitive recipients and limited access to water. This article aims to analyze how strategies were developed to meet sustainability requirements, if this solution has ensured good quantity and high quality after ten years of operation, and the extent of the project's economic impact on consumers. The project was analyzed as an evidence-based case study using semi-structured interviews, surveys, and document analyses. The study found that the chosen options succeeded in guaranteeing outstanding quality and secure delivery. Over $90 \%$ of water users were satisfied and had trust in it, and less than $3 \%$ were dissatisfied. The design time for withdrawal capacity has been extended from 30 to 50 years through planned measures. The study clarifies also that, due to some externalities, there has been virtually no economic impact on users. Bergaåsen is a clear case for the value of developing long-term strategies and implementing them in real life.
\end{abstract}

Keywords: Artificial recharge; groundwater sources; long-term planning; municipal water supply; water strategies; Växjö municipality in Sweden

\section{Introduction}

The quality of water resources for drinking water is not good everywhere, and in the case of surface water sources, these resources can quickly change in quality and quantity. These changes have been increasing with climate change through warmer water and increased occurrences of extreme weather, along with the risk of contamination [1]. If too little recharge is applied, groundwater is also likely to be contaminated and overexploited [2].

Access to raw water for producing drinking water from both surface water and groundwater in Sweden is good in general. However, half of Sweden's lakes and streams do not meet the requirements for good water status according to the European Union (EU) Water Framework Directive [2]. To meet the requirements, water resources must be used in the right manner and kept in good quality.

Fifty percent of municipal drinking water in Sweden comes from surface water, $25 \%$ comes from groundwater, and $25 \%$ comes from artificial groundwater [3].

Sweden is a member of the EU, and water regulations are based on EU directives that are then implemented in Swedish legislation. The Swedish Government and central authorities have the 
highest responsibility to ensure that Sweden complies with the EU framework. The 21 regional County Administrative Boards have, on the one hand, a connective role between people and municipalities; on the other hand, they have a connective role between the government and central authorities [2].

One obligation of the 290 local municipalities is to arrange water services that comply with directives that Parliament and the Government have issued. The Public Water Service Act regulates the municipalities' water services to ensure water supply and sewerage through a focus on sound financial management and good quality, both in short- and long-term plans [4]. However, planning that takes climate change and long-term urban planning into account is poorly regulated in Swedish national policy. Municipalities have a planning monopoly and apply this on an individual basis $[5,6]$. The lack of a general long-term strategy for water services is consistent with the results from both the sustainability index (SI) and studies financed by the Swedish Water and Wastewater Association (SWWA). The Swedish municipal Water and Wastewater (W and WS) organization has a functional capacity for operation but needs to be strengthened in order to develop long-term sustainable strategies [7]. Moreover, one of the conclusions from the SI analysis for 2017 is that increased strategic measures and investments are required to ensure long-term sustainability [8]. According to [4], two factors, among others, should make developing sustainable long-term strategies possible within municipal W and WS organizations: Active ownership and access to competent staff.

There were frequent problems with the quality of drinking water in the previous water treatment plant of Växjö (WTP) due to a shallow lake used for raw water abstraction that experienced eutrophication and elevated summer temperatures. The problems were temporarily managed from the mid-1980s, but politicians and consumers asked for better solutions. In 1998, Växjö conducted a comprehensive investigation to study the possibilities for its future water supply (FWS). Seven different options were studied and presented to local politicians, one of which was to rebuild the existing WTP. However, an option that involved the extraction of groundwater from the Bergaåsen-Berga Esker area was chosen to form the FWS of Växjö. The Bergaåsen area is located in Kronoberg county, in the municipality of Ljungby, $50 \mathrm{~km}$ west of Växjo. The Alvesta municipality, which is located between Ljungby and Växjo, is another with occasional problems with drinking water quality. Alvesta desired to be included in the same project as Växjo for its future water supply. Ljungby also desired to utilize Bergaåsen as a source for their water reserve, as they lacked their own reserve [9,10]. Figure 1 shows the location of the Bergaåsen project within the County of Kronoberg in Sweden.

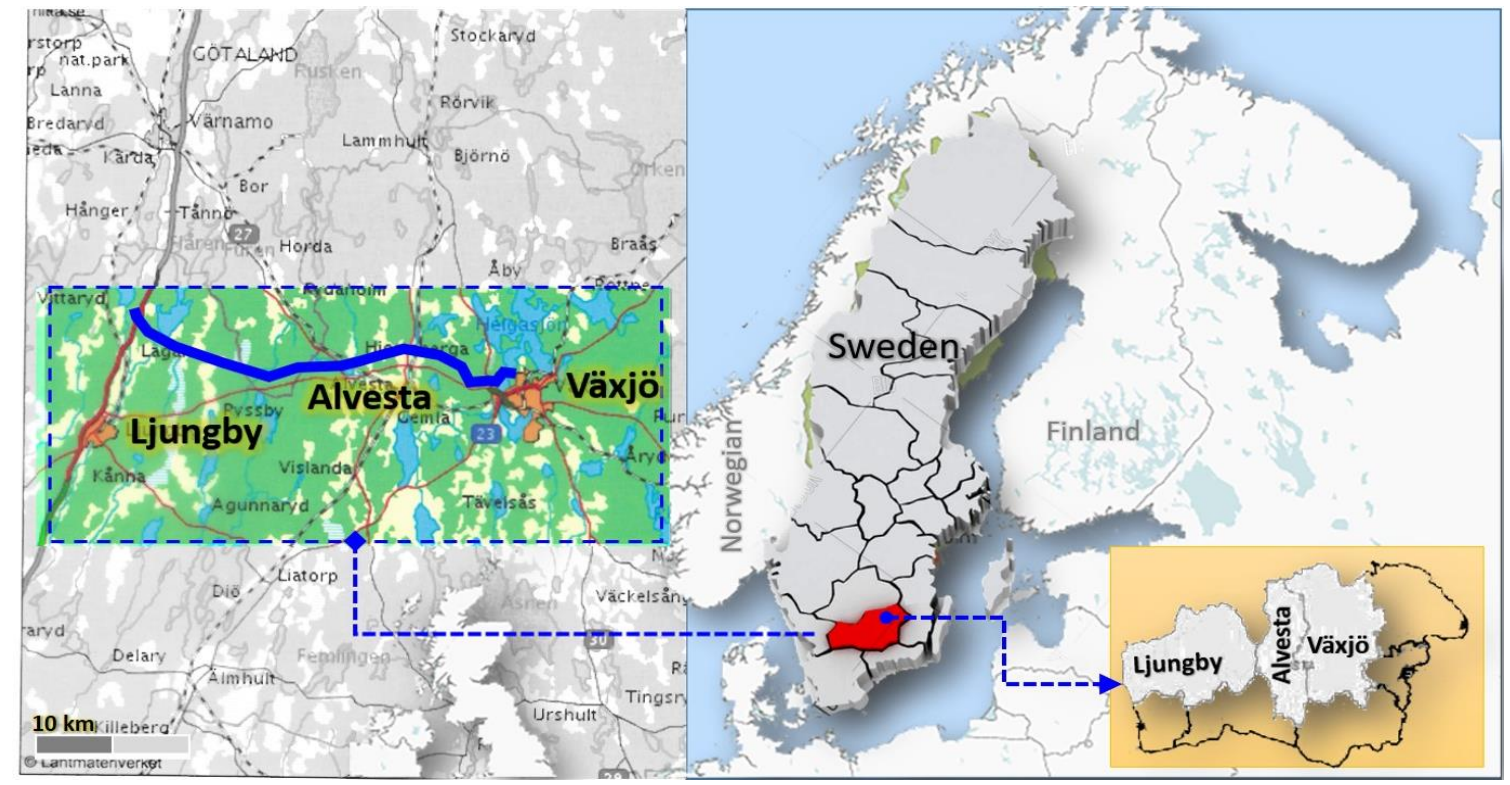

Figure 1. Location of the Bergaåsen project within the County of Kronoberg in Sweden. 
This study aimed, by analyzing the FWS project as an evidence-based case study to: (1) Show how strategies were developed and applied to meet sustainability requirements, as well as to inspire other municipalities to develop their long-term plans and strategies; (2) show if the FWS project of Växjö ensured water quality and quantity after ten years of operation; and (3) show if the investment in the FWS project economically affected consumers?

The study was guided by the following research questions:

- What did the entire process, from planning to implementing the FWS project, look like?

- What was the driving force for the building initiative of new WTP?

- How was the project technically built and how does it function?

- What was the impact of the investment on water fees?

\section{Materials and Methods}

An actual case of long-term developing plans, for municipal water management, was selected, studied, and analyzed. This case was the FWS of the Växjö municipality. It was chosen because it could reflect the capability of the municipality of Växjö to develop long-term plans, strategies, and processes within municipal W and WS services while many Swedish municipal W and WS organizations demonstrate shortcomings in developing long-term plans [4]. Additionally, the FWS of Växjö is one of the most significant, developed long-term planning projects in Sweden.

In 2010 an article was published, explaining in detail seven different alternatives for the future water supply of the Växjö Municipality and describing the motivations behind the chosen option [10]. Moreover, the study investigated the procedure of decision making and analyzed the assessment criteria to estimate the capacity of the Bergaåsen ridge [10].

Thus, this study shows a clear case for evidence-based management in the case of the FWS of Växjö, after ten years of operation. Previous articles and the unpublished internal documents from the department of W and WS of the Växjö municipality have been reviewed. The included data covered the entire process, from decision making to implementation, as well as the technical structure and function of the system. For collecting data, the following resources were used: Decision support tools, governing documents from national authority and from the Växjö City Council, the Global Sustainable Development Goals that were adopted in 2015 (SDGs, 2015-2030), the Swedish Water Sustainability Index that was developed by the Swedish Water and Wastewater Association (SWWA) over several years, and national and local laws and regulations. In addition, data from previous interviews, surveys made by the Central Bureau of Statistics were studied. Collected data were used to design a new comprehensive interview for the study with a list of several key questions. The focus was on answering the research questions, to meet the study's purpose, and to reach the study's goal. Figure 2 shows the methodological structure of the study.

The new interviews were performed by the author and a technical assistant who recorded the interviews with two recording units. Interviews were semi-structured and were conducted with two key persons from the municipality of Växjö. The first was the former head of the W and WS department who had the role of deciding, planning, and implementing the Bergaåsens project. The second respondent was the present head of the department who has the function of managing the project within the desired norms and objectives. To prepare the respondents, a list of the questions was sent to them before the interview. Each question included a brief background, based on the studied documents and collected data (described in more detail above).

Interview questions were arranged and categorized in four main areas: (1) Organization and decision support strategies, (2) impact on water fees, (3) quality assurance, and (4) lessons and advice. Finally, interview transcripts were written by the author.

The results of this study were based on analyzing the answers from the interviews, data from collections resources, previous articles, and internal documents from the W and WS department in the Växjö municipality. 


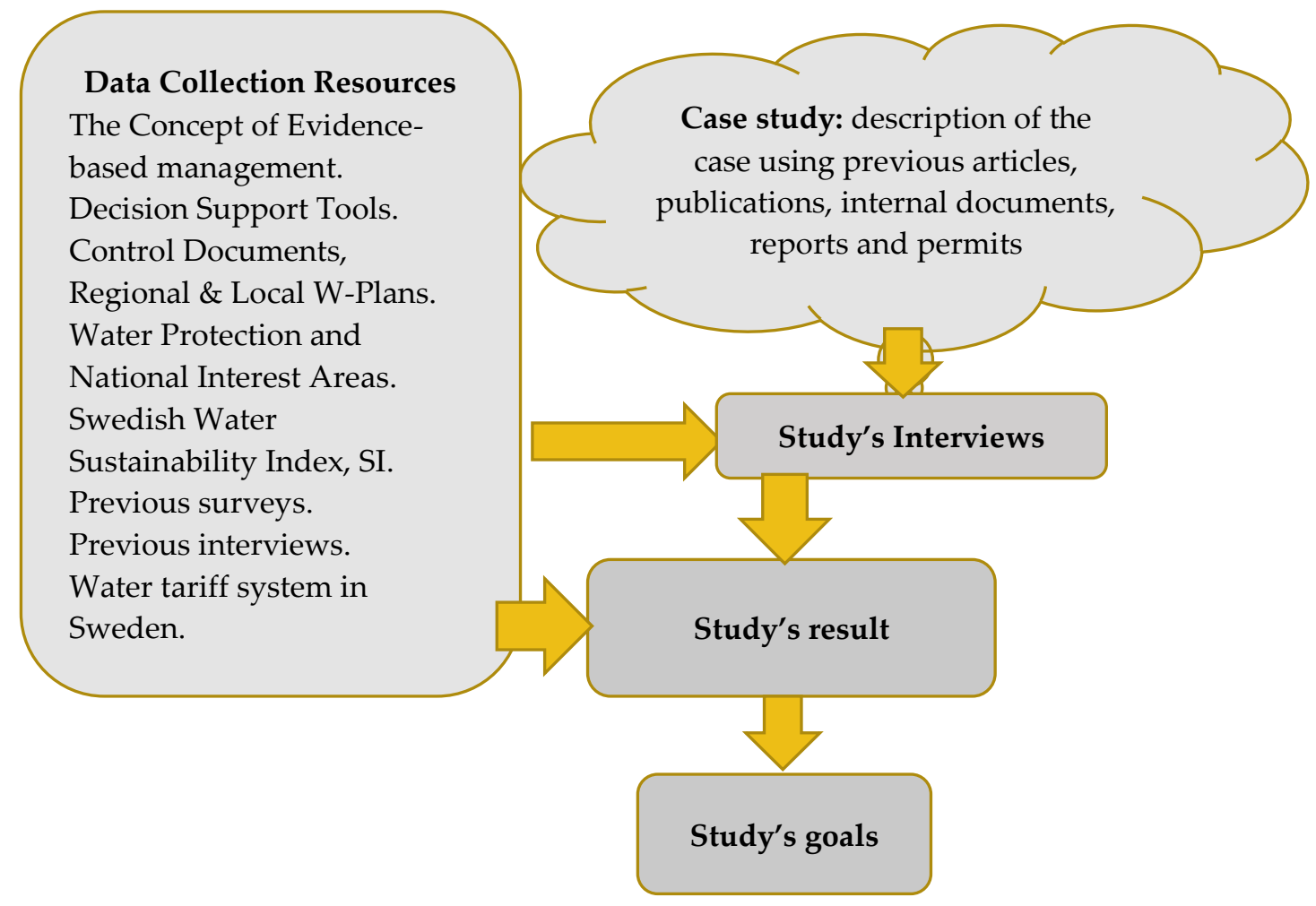

Figure 2. Methodological structure of the study.

\section{Data Collection Resources}

\subsection{Evidence-Based Practice or Management}

Evidence-based practice or management is an approach for decision making that helps practitioners to "critically evaluate the extent to which they can trust the evidence they have at hand." It also helps to identify, find, and evaluate additional relevant evidence for decisions [11]. With evidence-based practice or management, the best quality in decisions for long-term planning and strategies should be based on a combination of critical thinking and excellent available evidence. The possibility of a promising outcome increases if the decision process is based on "asking, acquiring, appraising, aggregating, applying, and assessing." The best available evidence from scientific literature, organizations, practitioners, and stakeholders should be considered [11]. When evidence comes from an organization, it is easy to determine likely causes and reasonable solutions, and it is more helpful when the analysis of organizational data reveals that customers are satisfied [11].

\subsection{Control Documents, and Regional and Local Water Plans}

Water management in Sweden, as in many other countries in Europe, is based on the EU Water Framework Directive, which has set the stage for the quality and availability of water, below which Sweden should not fall [12]. Since 2004, Sweden has been divided into five water districts run by independent water authorities. One county council in each district has been appointed by the government as the water authority and is responsible for decision-making and coordination [2]. Water authorities establish environmental-quality standards with quality requirements for all water bodies. For those waters that are in danger and not achieving good status, action needs to be taken, and their status must not deteriorate. That means that municipalities need to plan for municipal water issues, i.e., to make municipal water plans according to the EU Water Framework Directive. Municipal water plans are municipalities' instruments for effective action. They either include or link to a variety 
of other control documents, such as water supply plans, renewal plans for water facilities, wastewater management strategies, and strategies for local water management systems [2].

A municipal water supply plan is a control document describing, among other things, how the water supply plan is to be arranged throughout the municipality, and it includes (1) an overview and description of all water resources that are important for future drinking water supply, as well as (2) water requirements in the municipality for both the present and the future [13]. The water plan with the water supply plan can and should be used as the basis for a municipal overview plan [14].

The planning foundation for a municipal water supply plan is a regional water-supply plan, which is more general and comprises (1) an overview and description of all county water resources and (2) the future water requirements in the county. Regional water supply plans are mainly based on the hydrological knowledge of the Swedish Metrological and Hydrological Institution (SMHI) and the hydrogeological knowledge of the Geological Survey of Sweden (SGU) [13].

A regional water supply plan for Kronoberg County was prepared through the cooperation between the municipalities and the County Administrative Board in Kronoberg in 2008-2010. The purpose was to provide a planning basis for municipalities in the county as well as the county administrative board itself. The overall task of the plan was to highlight the water resources of current and future interest for the drinking water supply within the municipalities and the county. It should be noted that a regional water supply plan does not have to be too detailed, but municipal drinking water supply plans should be drawn up in detail for each municipality. It should also be planned to protect these prioritized water resources partly through water conservation areas and partly through community building planning [14].

The regional water supply plan for Kronoberg indicates that two lakes currently constitute water resources in Växjö, namely Innaren and the Stora Värmen. Lake Helgasjön was the water resource for the city of Växjö until 2009.

Interest in drinking water must be incorporated in the municipality's planning work to ensure that raw water is of high quality. Thus, water supply plans and the other water and wastewater plans are an essential basis for an overall water plan. Figure 3 shows the different aspects of a water plan.

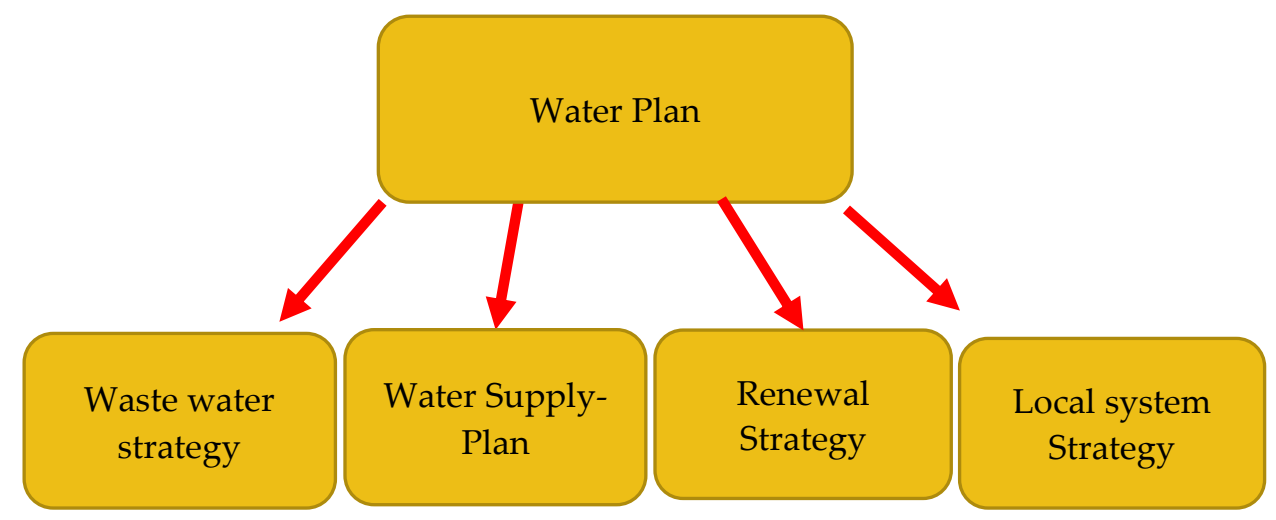

Figure 3. Water plan definition.

\subsection{Water Protection and National-Interest Areas}

Climate and vulnerability investigations point to several risks in the water supply chain, not least within the water supply's catchment area. It is essential to consider risks by risk analysis when designing a water protection area. Water sources from where raw water is taken and a sufficiently large part of the catchment area must, therefore, be protected against contamination [15]. An exclusive risk inventory and risk assessment document was made to assess the risk of negative impact on Bergaåsen from the surrounding area. The report described the environmental conditions in the catchment area that may affect water quality [9]. Once the Bergaåsen water supply scheme was in operation, the County 
Administrative Board of Kronoberg County established a protection area for it. The decision was made in October 2009 [15].

Furthermore, a Swedish agency can identify land and water areas of national importance for marine and water management as a national-interest area if the following criteria are met: (1) It can be used by many people, (2) it has high capacity and good quality, (3) it has a low risk of climate change, and (4) it is needed as a reserve or for future use.

A production area with raw water wells and infiltration ponds, as well as a transmission pipeline with associated facilities in Bergaåsen area, was designated as a national-interest area under the Environmental Code of the Sea and Water Authority in September 2016. The area is protected from actions that could damage its value or make it challenging to utilize the reserve areas. Delimitations and a value description were made for this decision [16]. This is in line with the water safety plan that was recommended by the World Health Organization (WHO).

\subsection{Sustainability Index (SI)}

The sustainability index (SI) survey is a tool developed by the Swedish Water and Wastewater Association (SWWA) to support municipal W and WS organizations to self-analyze and ensure the sustainability of their services and management in the short and long term. One of the primary purposes of developing an SI was to use the municipality's outcomes from the SI as a basis for dialogue between the organization's executives and municipal policymakers regarding the development, priorities, and investments of the organization's activities $[7,8]$. The SI consists of three main areas which are divided into a total of 14 parameters. These areas are (1) sustainable services for users, (2) environmental sustainability, and (3) sustainable resources. Each area consists of specific parameters within the same area, and below each parameter, there are several questions. [7]. Healthy/Safe Water, Security of Delivery, Satisfied Customer are some of the parameters which belong to the area "Sustainable Services for Users." The questions are asked to the municipal W and WS organizations. The questions and their answers constitute input in the SI survey. Color indices are applied for both questions and parameters. The use of a green color for the parameter indicates that almost all questions for the parameter have a positive (green) answer. Yellow means that the used routine should be improved for one or more questions piled up under the parameter. Red indicates that measures must be taken to improve the sustainability of the service, with one or more questions below that parameter then being colored red [8,17]. Table 1 shows an example of the parameter of "Satisfied Customer," related questions, and their answers for the Växjö municipality [18-21].

Table 1. Example of the parameter of "Satisfied Customer," related questions, and their answers for the Växjö municipality [18-21].

\begin{tabular}{ccc}
\hline Code & Parameter/Questions & Answers \\
\hline & 6- Satisfied Customer & \\
\hline Tn 1 & $\begin{array}{c}\text { Are the Satisfaction for users of W \& Ws services measured? (Also } \\
\text { specify what type of satisfaction survey used (e.g., Done by Central } \\
\text { Bureau of Statistics (SCB), Satisfied Citizen Index (NMI), or Statistics } \\
\text { of Swedish Municipalities \& the Regions (SKL), ...) }\end{array}$ & Yes \\
\hline Tn 2 & Are user surveys used to improve the operations? & Yes \\
\hline $\operatorname{Tn} 3$ & Satisfied Water User & $\begin{array}{c}\text { Very great confidence. Over 90\% are } \\
\text { satisfied and less than 3\% dissatisfied. }\end{array}$ \\
\hline
\end{tabular}

Table 1 shows that over $90 \%$ of water users were satisfied, and less than $3 \%$ were dissatisfied.

This result, together with the answers to the questions with the Tn1 and Tn2 codes, were positive and gave cause for green color for the parameter "satisfied customer."

The sustainability-index survey is voluntary and has been carried out each year since 2014 . The number of participating utilities increases every year. Each year, national analysis is done based on the results. A crucial conclusion from these analyses is that water and sewage services in Sweden currently have a good status, but many municipalities need to improve their long-term planning to 
ensure long-term sustainability. Smaller W and WS organizations mainly seem to be actively operating with insufficient resources for strategic and long-term plans [4,8].

The results of the SI survey for the Växjö municipality's parameters concerning drinking water show that "safe water for health," "security of delivery" (delivery reliability), and "satisfied customers" had a green color for the years 2015-2018, during which Växjö participated in the survey [18-21].

\subsection{Citizen Surveys by the Statistics Central Bureau SCB}

Previous citizen surveys in the Växjö municipality were carried out in 2006, 2008, and 2010. The results showed that there were areas in which Växjö made improvements that were directly reflected in citizen answers in the survey. An example of an improvement was the new drinking water treatment plant from Bergaåsen. The assessment of satisfaction, i.e., the Satisfied Citizen Index (NMI) about W and WS services increased from an NMI of 62 in 2006, to 78 in 2010, and to 83 in 2012 [22].

Växjö also participated in the citizen survey in the spring of 2012, 2014, 2016, and 2018. Throughout these years, the citizen survey showed an NMI of 80-82 out of 100 for W and WS services in Växjö. This NMI was higher than all other activities in the municipality [23].

\section{Case Study}

\subsection{Växjö and Alvesta Municipalities in General}

The Växjö municipality consists of the city of Växjö and more than ten other small communities. At the end of 2009, approximately 81,500 inhabitants lived there. At the end of 2017, the number of inhabitants was about 91,000, of which approximately 63,700 lived in the city of Växjö, about 18,200 lived in the smaller urban areas, and the rest (approximately 9100) lived in rural areas. At the end of 2018, the number of inhabitants was 92,542 [24].

The Alvesta municipality is located within Kronoberg County and consists of six urban areas, of which the city of Alvesta is the largest. Alvesta has close to 21,000 inhabitants [25]. The population of the municipality in 2009 was more than 18,800 , of which about $70 \%$ were residents in the municipality's urban area.

\subsection{Earlier Water Supply in Växjö: Motivation for Planning Future Water Supply}

The WTP-Sjöudden—was built in 1887 and underwent extensive renovation and extension in 1957. It supplied the city of Växjo with drinking water until the Bergaåsen water supply scheme was applied in 2009. The Sjöudden WTP was based on surface water from Lake Helgasjön. The latest extensive renovation and extension was carried out in it in 1969. The intake of the treatment plant was from Lake Helgasjön at the eastern coast of the Öjaby inlet, which was surrounded by a traffic route, streets, buildings, and an industrial area [10].

The quality of drinking water in Växjö in the 1980s did not meet the current limit values and created problems for consumers in terms of temperature, smell, taste, and sometimes elevated levels of manganese and aluminum residues. Problems with bacteria and mold occurred in 1984-1986, which is why temporary measures were taken in the WTP. In the late 1980s, the Växjö municipality was aware of the necessity of finding alternative solutions for a future water supply. Therefore, a study was conducted that resulted in two proposals for a future water supply, one with surface water and the second with infiltrated water through artificial recharge as a raw water source. Further investigations were recommended for the second proposal, but the decision by municipal authorities (politicians) gave higher priority to the construction of the new wastewater treatment plant (WWTP), which was more urgent. The status of the Sjöudden WTP gradually worsened, and a comprehensive status survey was conducted in 1998. It showed many deficiencies in several areas, such as processing, construction, and machinery [10].

Furthermore, in 1998, the Växjo municipality, together with many other municipalities, carried out a questionnaire investigation to form an opinion of how the municipality's residents experienced 
the quality of their drinking water. The results showed that consumers in Växjö were dissatisfied, as they rated drinking water in Växjö at the second-last position concerning contributory municipalities. The questionnaire also showed that most satisfied consumers lived in municipalities with a drinking water supply based on groundwater [10].

\subsection{Process of Choosing FWS for Växjö Municipality}

At the end of the 1990s, the existing Sjöudden WTP needed to be adjusted and improved as soon as possible in anticipation of better solutions that politicians and consumers demanded.

Through an inventory, it was shown that there are four lakes and four sand and gravel formations (ridges) in Kronoberg County. They were considered as possible raw water sources for future water supply in Växjö. Allgunnen, Helgasjön, Vidöstern, and Örken are the four lakes, and the ridges are Braåsen, Nybroåsen, Vislandaåsen, and Bergaåsen. In 1997, the Växjö municipality decided to perform a comprehensive investigation of alternatives for the FWS of Växjö. Seven options were evaluated and presented in 1998. Figure 4 shows the lakes and ridges that were considered as possible raw water sources for water supply in Kronoberg County as well as the location of the six suggested alternatives. Alternative 7 was rebuilding, extending, and changing the intake of the existing WTP to be in function for 15-20 more years. Emergency measures that cost several million SEK were carried out on the existing plant to keep it in operation until the chosen alternative could be taken into operation [10].

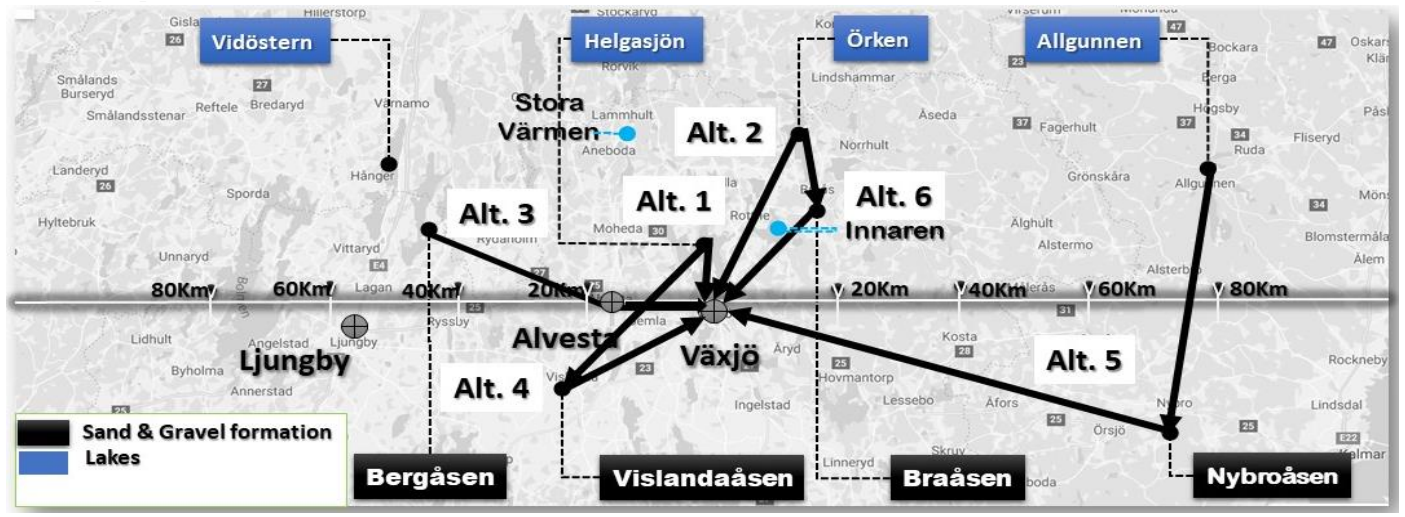

Figure 4. The map of possible raw water sources in Kronoberg County and the location of Alternatives 1-6.

Alternatives 1 and 2 were based on the supply of raw water from surface water. It was planned to erect a new WTP near the existing WTP at Sjöudden. The raw water would be taken from Örviken inlet in Helgasjön Lake and Örken Lake and pumped to a new WTP in Sjöudden. The raw water would undergo manganese reduction and alkalization in addition to traditional chemical treatments [10].

Alternative 3 was based on groundwater resources, i.e., supplying and conveying groundwater from the Bergaåsen in the Ljungby municipality, 50 kilometers away from Växjö.

Alternatives 4 and 5 were based on artificial groundwater. Alternative 4 meant that water would be pumped from Örviken inlet in Helgasjö Lake to infiltrate through Vislandaåsen. Alternative 5 suggested that groundwater in the Nybroåsen ridge would be strengthened with infiltration water from Allgunen Lake. To protect the ridges, the over-pumped water from the Örviken inlet and Allgunen Lake would be pre-treated through chemical precipitation before infiltration.

The groundwater would then be pumped up from several groundwater wells in the ridges. After $\mathrm{pH}$ adjustment and alkalization, the water would be pumped to the Sjöudden WTP in Växjö, where it would be disinfected before distribution to consumers. [10].

Alternative 6 was based on a combination of surface water and groundwater. Raw water would be taken from Lake Örken to be infiltrated through the Braåsen gravel formation within the community's Braås WTP. Investigations on Braåse ridge showed that only a small part of it could be used because the ridge was mostly broken. The little ridge formation meant that the retention time for the infiltrated 
water would be too short and would be considered to be equivalent to a slow filter in a waterworks. Supplementary surveys in Braåsen showed that the formation capacity was limited. Alternative 6 was therefore deemed not feasible [10].

Table 2 shows the estimated investment costs that were stated in 1998 for Alternatives 1-5 and Alternative 7.

Table 2. Estimated investments cost for Alternatives 1-5 and Alternative 7 for 1998 [9].

\begin{tabular}{cc}
\hline Alternatives for FWS in Växjö & Estimated Costs for 1998, in Mil SEK \\
\hline Alt. 1 & 160 \\
Alt. 2 & 225 \\
Alt. 3 & 220 \\
Alt. 4 & 270 \\
Alt. 5 & 500 \\
Alt. 6 & Cancelled \\
Alt. 7 & 130 \\
\hline
\end{tabular}

Considering the high investment costs calculated in 1998 for Alternatives 4 and 5, as Table 2 shows, these were not regarded as attractive for more study. The costs for Alternative 3 included 20.2 million SEK used up to January 2001 for drilling, test pumping, investigations, etc.

An annual cost diagram for Alternatives 1,2, 3 and 7 was presented for the capital costs of investments and reinvestments. Additionally, the costs of operation and maintenance for 50 years were added, and, the updated values of 20.2 million SEK for Alternative 3 were added to the calculation for all alternatives. The diagram showed that Alternative 2 was by far the most expensive option and Alternative 3, Bergaåsen, was the cheapest alternative throughout the entire period, i.e., 50 years. The reason is mainly that Alternative 3 contained a large proportion of investments with long depreciation periods [10].

Following the general assessment made in 1998, it was confirmed that Bergaåsen could supply Växjö with good-quality drinking water at a high enough quantity. The project group then suggested that further investigation should primarily focus on in-depth investigations in Bergaåsen (Alternative 3 ) in order to clarify the possibilities for the future groundwater supply for Växjö. Many studies were then conducted, including about 140 drilling surveys starting in 1998, to map the geological structure and the aquifer extension in the area of Bergaåsen, thereby estimating the capacity of the Esker area. Based on the results, Alternative 3 was chosen by the technical board in January 1999.

Extensive test-pumping programs, including long-term test pumping, continued to be performed over four years. With results from all surveys and test pumping that were carried out as a basis, a mathematical computer-based groundwater model of parts of the Esker area was constructed. With the help of this model, it was possible to simulate the flow and level variation at different apportions of abstraction and infiltration $[9,10]$.

System documents were then prepared that described how groundwater production should be carried out and how water could be transferred to Alvesta and Växjö, as well as facilities required for such actions. The decision to realize the Bergaåsen project was then made by the Växjö municipality council in August 2001. An application for the permission of water abstraction according to the environmental code was submitted to the Environmental Court in Växjö in December 2001. The Environmental Court expressed its positive opinion in January 2004 and handed over the issue to the government for a trial. The administrative process took seven years from the initial investigation 1997 to the application for the permit in 2004. The government positively commented in February 2005 [10].

Bergaåsen is extensive and has an up-to- $50 \mathrm{~m}$ thick sand and gravel formation; the water conveying part is up-to-35 m thick. The part of Bergaåsen that is of interest (see Figure 5) is bounded to the west by Lagan River and bounded the east by the new and the old national highway (E4). The area, which is just over $3 \mathrm{~km}$ long and $1 \mathrm{~km}$ wide, is divided into three parts: North Hallsjö, Central Hallsjö, and South Hallsjö. 


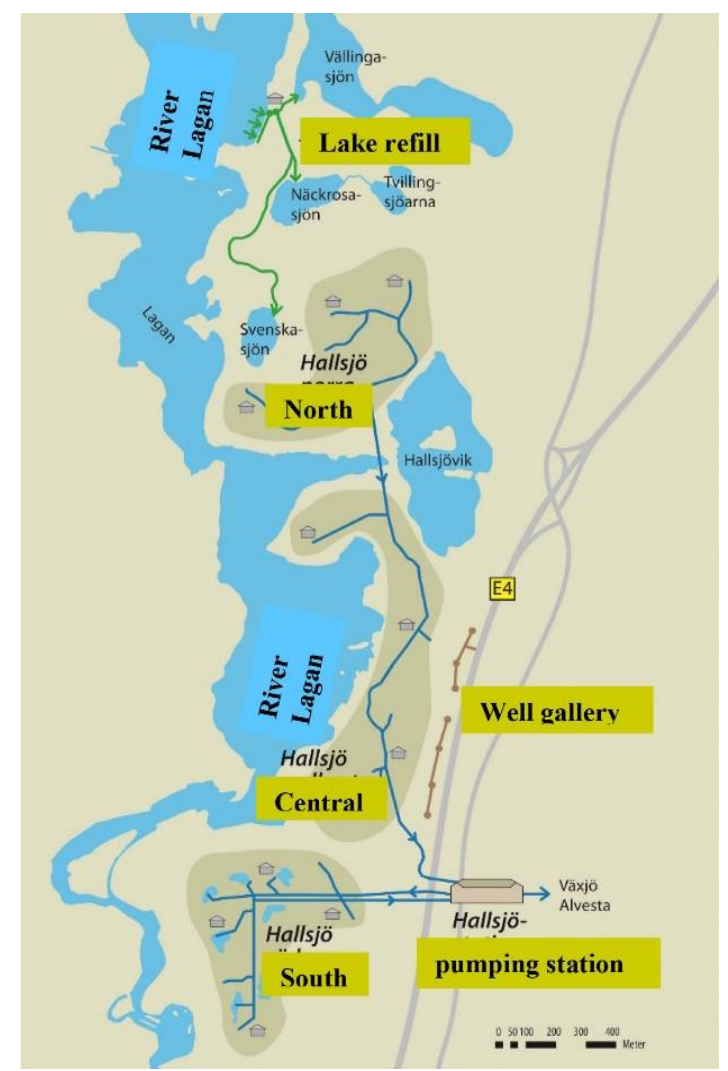

Figure 5. Bergaåsen area [10].

The water production area is divided into zones for raw water abstraction in North Hallsjö and a part of Central Hallsjö, as well as zones for the recharge and primary production of drinking water, located in South Hallsjö. Two other areas in South Hallsjö are being kept as future reserve areas to produce drinking water in 2030-2050.

The design time of the water supply was set at about 30 years, i.e., until 2030, but flexible measures were proposed as a basis for extending the design time to at least 50 years. One of these applied measures was inducing water from the Lagan River into the aquifer. The other measure was dividing the whole area into several areas for producing water now and in the future, as Figure 5 shows.

\subsection{Design and Function of Bergaåsen Project as Initially Designed}

Raw water is pumped up from 17 wells in the abstraction zone in North Hallsjö, then pH-adjusted and alkalinized through the addition of carbon dioxide (CO2) and limestone (CaCO3). Water is then transmitted to the southern area to be slowly re-infiltrated in the re-infiltration ponds to adjust Fe and Mn level in order to guarantee that changes in the groundwater table are kept small and to minimize any induced water inflow from Lagan River into the groundwater while it is pumped through the clean water wells. The residence time for the re-infiltrated water in groundwater formation before reaching the clean water wells is expected to exceed 14 days, which in Swedish drinking water standards is regarded as enough to obtain good-quality groundwater. The pumped water from the raw water area, i.e., North Hallsjö, is gradually replaced by induced infiltration from Lagan River through the water banks and the river bottom. Total transmission time through all ponds exceeds 100 days $[9,10]$. The water that is pumped up through 22 clean water wells is again led to the pumping station at Hallsjö to be further pH-adjusted with $\mathrm{CO}_{2}$ and soda $\left(\mathrm{Na}_{2} \mathrm{CO}_{3}\right)$; then, the water is pumped toward Alvesta and Växjö. Figure 6 shows the schematic basis for the water supply system in Bergaåsen. 


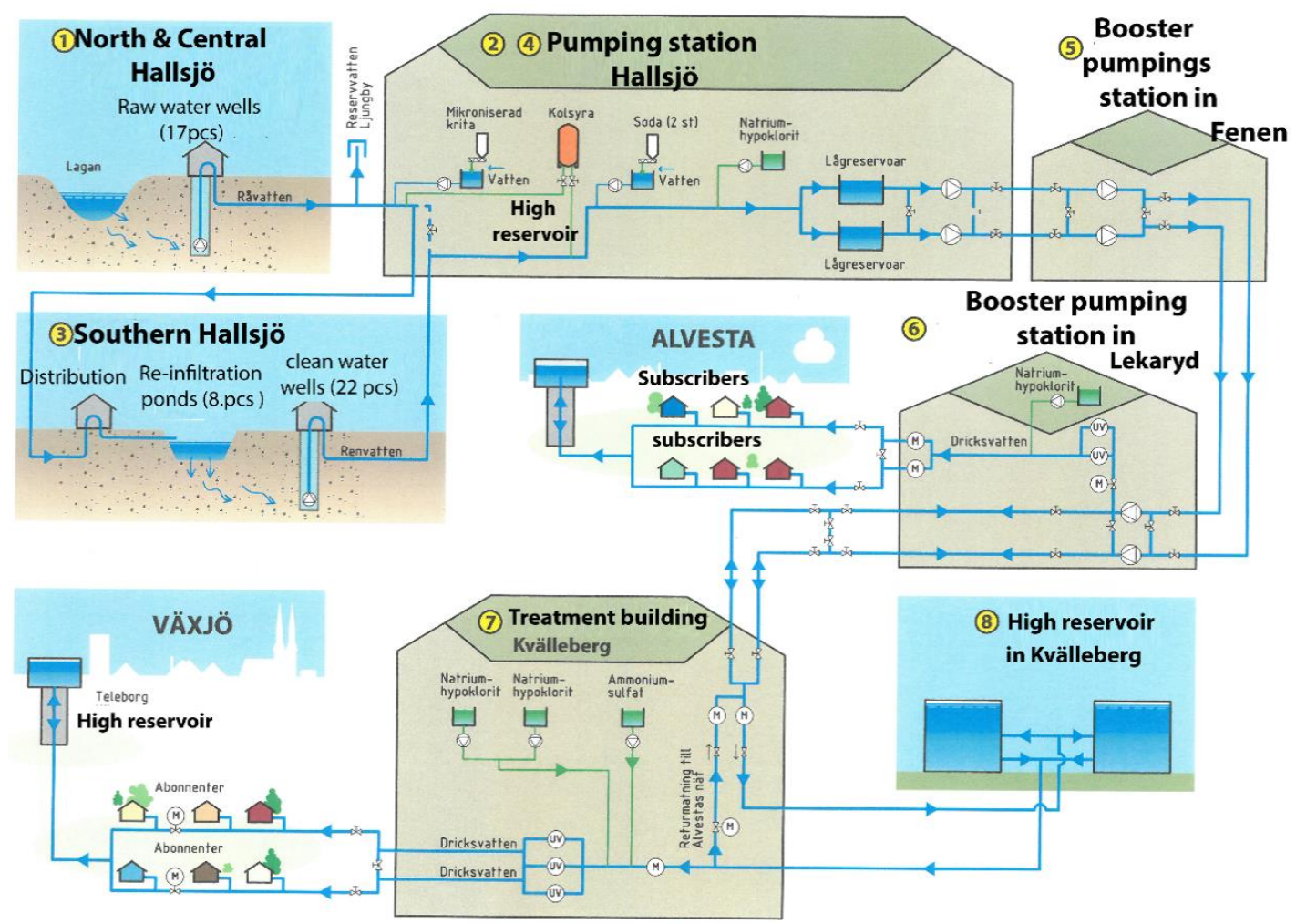

Figure 6. Schematic basis for water supply system in Bergaåsen [10].

The forecast for the connected population to Bergaåsen for 2030 was $62,000-72,000$ people, and a few thousand more connected people from other municipalities if these are connected to the Växjö FWS [26].

Bergaåsen supplies drinking water to the city of Växjö, eight other small urban areas within the Växjö municipality, the city of Alvesta, and three other small urban areas within the Alvesta municipality.

Today, Bergaåsen supplies about 200 liters of water per second, $24 \mathrm{~h}$ a day, to about 83,000 users, of which approximately 73,000 live in the Växjö municipality. Water is transported via two parallel, $50 \mathrm{~km}$-long water pipelines. Results from all conducted studies and other tests showed that withdrawal capacity goes beyond a 30-50-year perspective $[9,10]$.

\section{Results and Discussion}

\subsection{Interviews, Responses, and Discussion}

On 25 October 2018, extensive semi-structured interviews took place with two key persons in the Växjö municipality, the previous and the new head of the W and WS department in Växjo-Pehr Andersson and Steve Karlsson, respectively.

Pehr Andersson began as the W and WS head in 1987 and continued his leadership for 30 years. During his leadership, several strategic projects were achieved in Växjö. He was awarded the Water prize by the SWWA in 2017 for his drive and involvement in several large water projects, including the new sewage-treatment plant, new technology for stormwater, and a new supply of drinking water (the Bergaåsen project). These projects have benefited Växjo residents and have also been nationally recognized.

Steve Karlsson started in 2015 as the new department head when Pehr Andresson retired. However, Pehr Andersson is still working as a specialist consultant in the department.

The interview, which lasted about three hours, included several key questions and many sub questions. Interview questions were categorized according to the study's questions into the four following areas: 


\subsubsection{W and WS Organization and Decision-Support Strategies}

Based on the Water Services Act, the municipality always owns the W and WS infrastructure. However, organizational forms may vary, including traditional organizations, municipal or privately-owned companies, public multiutilities, private multiutilities that manage their companies without politician influence, and merged organizations that consist of several municipalities within a region [4]. The main reasons for building a merged organization are to ensure competence, meet future environmental challenges, and ensure the development of long-term activities by making joint investments in facilities or in new technologies that individual municipalities are not able to finance [27]. Furthermore, such organizations make a platform available to experience exchange. There are also risks with these forms of organizations: Increased distance, responsibility issues, and reduced local political influence. In other words, the political influence of the municipality's politicians decreases when politicians from several municipalities direct a typical organization [28].

The form of the W and WS organization at the Växjo and Alvesta municipalities is the traditional type, i.e., with politician influence and active ownership. Active ownership constitutes an internal relationship, which means that it is the municipality on its own that can create conditions for long-term sustainable responsibility [4]. Active ownership hence includes both political and administrative leadership [29]. However, there are some disadvantages in being a traditional W and WS organization i.e., to be a part of several parts of a community-building administration under the responsibility of the technical board that has several issues in the municipality. In such organization, sometimes occurs situations when W and WS issues do not receive the attention they should and instead deprioritized [4].

The political superstructure of a traditional organization consists of a technical board, i.e., all questions that go to the municipal board are implemented according to what is decided by the technical board. The decision of the technical board is, in turn, based on documentation from the technical office [5].

The Växjö municipality has not had any plans for building a more extensive or joint organization to run the W and WS sector, and it has never been asked by another municipality to be included in a joint organization, according to Steve Karlsson (2018). He expressed that the W and WS department is satisfied with a traditional organization, and regular meetings of the heads of municipal W and WS organizations from the entirety of Sweden are an effective strategy for experience exchange.

Decisions are typically made based on many factors and criteria. In line with previous studies and a new study by [5], critical events have, in some cases but not always, pushed urban water issues into the political agenda. In line with this finding, several complaints about water quality worked as an alarm and raised politicians' awareness for the need to act and finance; however, this took 12 years to get full attention. When Pehr Andersson was recruited as the head of W and WS, he received the green light to make decisions and find solutions for the problems facing the Växjö water supply. Emergency measures were immediately taken to keep the WTP functioning within accepted limits. Surveys within 30 kilometers from Växjö were conducted to find new water resources. Two eskers and some lakes in the Växjö municipality and vicinity were found and investigated, one in Braås and the other in Alvesta Vislanda. Artificial groundwater via infiltration through the Vislanda ridge was then suggested to be the new water resource for Växjö. However, plans were paused, as it was impossible to run two large projects, i.e., the WTP and the WWTP, in parallel with the operational ability of the W and WS department. The need to pause the WTP was apparent when the county administrative board required immediate action on the WWTP, as the situation was more difficult and short-term measures on the old WTP also yielded acceptable results. In 1999, it was possible to initiate the WTP project since the new WWTP was completed.

Pehr Andersson dared, after much experience in this field at Växjö (from 1987 to 1999) to enlarge the investigation radius for a suitable raw water supply to the city from 30 to about $200 \mathrm{~km}$ outside of Växjö by starting a survey from maps of the SGU and then continuing the investigations in the field. Based on the results, six alternatives were tested and then technically and economically analyzed against each other, resulting in the choice of the Bergaåsen project for the FWS of the Växjö municipality (see Figure 4). 


\subsubsection{Functioning and Operation Processes}

Bergaåsen could be monitored from the manager's office in the municipal house, as Pehr Andersson stated in a 2009 interview. Explaining how this happens, he stated that Bergaåsen is the first fully computerized gravel formation in Sweden. Over a hundred analog level meters exist, by which the groundwater level, inside, outside and in the terrain between each well can be followed. Exactly how groundwater surfaces stand and the amount of water in the magazine can be controlled could thereby be seen online. About 10,000 signals can be monitored through an alarm limit for every parameter.

It was designed to initially treat raw water with $\mathrm{CO}_{2}$ and $\mathrm{CaCO}_{3}$ in the pumping station before re-infiltration to adjust the $\mathrm{pH}$ level. Pehr Andersson was asked if this method was still suitable and usable. He stated that two changes in the initial concept of the processing technology came about during these ten years of operation.

The first was discontinuing treatment with $\mathrm{CO}_{2}$ and $\mathrm{CaCO}_{3}$ before re-infiltration, which was assumed from the beginning because the first tests showed a very low alkalinity in the raw water. However, this idea changed after driving the project, as alkalinity increased in the raw water. $\mathrm{CaCO}_{3}$ had also caused many operating problems.

The second change was replacing the two big silos for $\mathrm{CO}_{2}$ and $\mathrm{Na}_{2} \mathrm{CO}_{3}$, which was initially done to adjust $\mathrm{pH}$ level and alkalinity in the clean water before transporting it to Alvesta and Växjö. They were replaced with lye $(\mathrm{NaOH})$ tanks; then, an entire lye structure with glass walls and sliding doors was built, and many additional working environment measures were taken. These two changes were made because of concerning problems with using $\mathrm{Na}_{2} \mathrm{CO} 3$ and $\mathrm{CaCO}_{3}$.

\subsubsection{Impact on Consumers}

The operations of water and wastewater organizations are entirely based on fees from the municipality's W and WS users. This means that W and WS organizations carry out their business by being self-sufficient through water fees paid by all users. This also means that no tax assets are used and that the business is not profitable. Water fees are used for producing drinking water, maintaining and renewing pipe networks and associated facilities, and caring for and treating wastewater and stormwater. Fees also cover capital loan costs, and, for investments in W and WS networks, W and WS treatment plants and cover administration. The allocation of water charges differs between municipalities. In the Växjö municipality, $45 \%$ of the fees go to capital costs, $40 \%$ go to operating and maintaining the facilities, and the rest go to staff and administration costs [30].

Fees are suggested by W and WS organizations and decided by the municipal council [4]. In order to understand the process of suggesting and determining water fees and which factors affect its size, Steve Karlsson explained that in June of each year, the W and WS department presents a budget forecast for politicians to decide next year's water fees. In this forecast, the department assesses how costs would look next year, which investments would be made, and all other factors that could affect expenses. When the politicians decide the fees, the W and WS department then knows what they should count on and if the fees are enough when they draft their detailed budget for the next year. Based on that, they select activities and investments that they may be able to perform and make with the decided fees, thus postponing the rest of the suggested investment until the following year.

In general, water fees are composed of two parts: Consumption fees and connection fees. Connection fees are paid once by the property owner for connecting the property to municipal water and sewers.

Consumption fees in the Växjö municipality consist of (1) the fixed base fee, of which the amount is based on how much water is required for the property and thus on the number of water meters and their size; (2) the variable fee, which is based on how much water is consumed in the property; (3) the stormwater fee for the streets; and (4) the stormwater fee for the property [30]. The prices of the water consumption fee in Växjö for 2008 (before the start of the Bergaåsen project), 2012, 2013, 2017, and 2018 are shown in Table 3 [30-32]. 
Table 3. Consumption fee for Water and Wastewater (W and WS) in the Växjö municipality for 2008, 2012, 2013, 2017, and 2018 [30-32].

\begin{tabular}{cccccc}
\hline Type of Fee & $\mathbf{2 0 0 8}$ & $\mathbf{2 0 1 2}$ & $\mathbf{2 0 1 3}$ & $\mathbf{2 0 1 7}$ & $\mathbf{2 0 1 8}$ \\
\hline $\begin{array}{c}\text { Fixed fee in SEK/year and measure } \\
\text { point for W, WS, and stormwater }\end{array}$ & 2700 & 2975 & $3095^{*}$ & $3531^{*}$ & $3658^{*}$ \\
Fee in SEK/m3 for water & 10.5 & 12.00 & 9.00 & 9.6 & 9.6 \\
Fee in SEK/m3 for wastewater & 13.00 & 13.00 & 10.00 & 10.40 & 10.4 \\
\hline
\end{tabular}

* Fee for stormwater included.

As Table 3 shows, the rate of increase in the fixed portion, from 2700 SEK in 2008 to 3658 SEK in 2018, has been $3.5 \%$ per year. This rate is a marginal increase and has mostly been due to inflation [33]. However, the price of water consumption per cubic meter dropped from $10.25 \mathrm{SEK} / \mathrm{m} 3$ in 2008 to $9.6 \mathrm{SEK} / \mathrm{m} 3$ in 2018.

The Växjö municipality introduced a new fee system for stormwater in January 2013 to meet climate-change demands. However, when the new stormwater charge system was introduced, the consumption fee for wastewater dropped from 13.0 SEK in 2008 and 2012 to 10.0 and 10.4 SEK in 2013 and 2018, respectively.

The average costs per year of the consumption fee for a type A standard house in the Växjö municipality are shown in Table 4 for 2008 and 2011-2018 [34].

Table 4. Average costs of consumption fees for type A house in the Växjö municipality, given in SEK/year. [34,35].

\begin{tabular}{cccccccccc}
\hline $\begin{array}{c}\text { Consumption } \\
\text { Costs }\end{array}$ & Year & Year & Year & Year & Year & Year & Year & Year & Year \\
\hline SEK/year & 5808 & $\mathbf{2 0 1 1}$ & $\mathbf{2 0 1 2}$ & $\mathbf{2 0 1 3}$ & $\mathbf{2 0 1 4}$ & $\mathbf{2 0 1 5}$ & $\mathbf{2 0 1 6}$ & $\mathbf{2 0 1 7}$ & $\mathbf{2 0 1 8}$ \\
\hline
\end{tabular}

As Table 4 shows, that the average annual consumption fee in the Växjö municipality in 2018 for a typical type A house was 6660 SEK. This fee is $8 \%$ less than the average of the annual consumption fee for Swedish municipalities in 2018 (7291 SEK) for the same house type, A, as Tables 4 and 5 show [36]. Table 5. Shows, the average annual consumption fee for W and WS in 2018 for typical type A house for all municipalities in Sweden [36].

Table 5. Average annual consumption fee for W and WS in 2018 for typical type A house for all municipalities in Sweden [36].

\begin{tabular}{cccc}
\hline & Average Annual Fee 2018 in SEK & Change Compared with 2017 & SEK/Property and Month \\
\hline Type A House & $7291 \mathrm{kr}$ & $+3.0 \%$ & 608 \\
\hline
\end{tabular}

The average connection-fee costs per year for a typical type A house in the Växjö municipality are shown in Table 6 [35].

Table 6. Average costs of connection fees for a type A house in the Växjö municipality, given in SEK/year [35].

\begin{tabular}{ccccccccc}
\hline & Year & Year & Year & Year & Year & Year & Year & $\begin{array}{c}\text { Year } \\
\mathbf{2 0 1 1}\end{array}$ \\
& $\mathbf{2 0 1 2}$ & $\mathbf{2 0 1 3}$ & $\mathbf{2 0 1 4}$ & $\mathbf{2 0 1 5}$ & $\mathbf{2 0 1 6}$ & $\mathbf{2 0 1 7}$ & $\mathbf{2 0 1 8}$ \\
\hline Connection fee & 101,464 & 111,615 & 122,773 & 155,607 & 171,000 & 188,100 & 206,910 & 227,585 \\
\hline $\begin{array}{c}\text { Increasing rate between } \\
\text { two following years }\end{array}$ & & $9.9 \%$ & $9.9 \%$ & $26.7 \%$ & $9.9 \%$ & $10 \%$ & $10 \%$ & $10 \%$ \\
\hline
\end{tabular}

The connection fee in Växjö was 227,585 SEK in 2018, as shown in Table 6. This fee was $64 \%$ higher than the average connection fee of Swedish municipalities, which was 138,651 SEK, as shown in Table 7. 
Table 7. Average connection fee for all Swedish municipalities in 2018 [36].

\begin{tabular}{ccc}
\hline & Average Connection Fee in Sweden Municipalities & Change Compared with 2017 \\
\hline Type A House & 138,651 & $4.2 \%$ \\
\hline
\end{tabular}

However, the spread in the connection fee between the municipalities in Sweden was high.

This was between 37,500 and 274,000 SEK, as shown in Figure 7. The connection fee in the Växjö municipality was $17 \%$ less than the highest one, 274,000 SEK. The connection fee partly relates to the real costs of connecting a property to the W and WS systems and partly to the share that municipalities choose to charge that part of the fee to finance the W and WS sector. On the other hand, some municipalities choose to finance the remaining share from the income from the consumption part of fees [36].

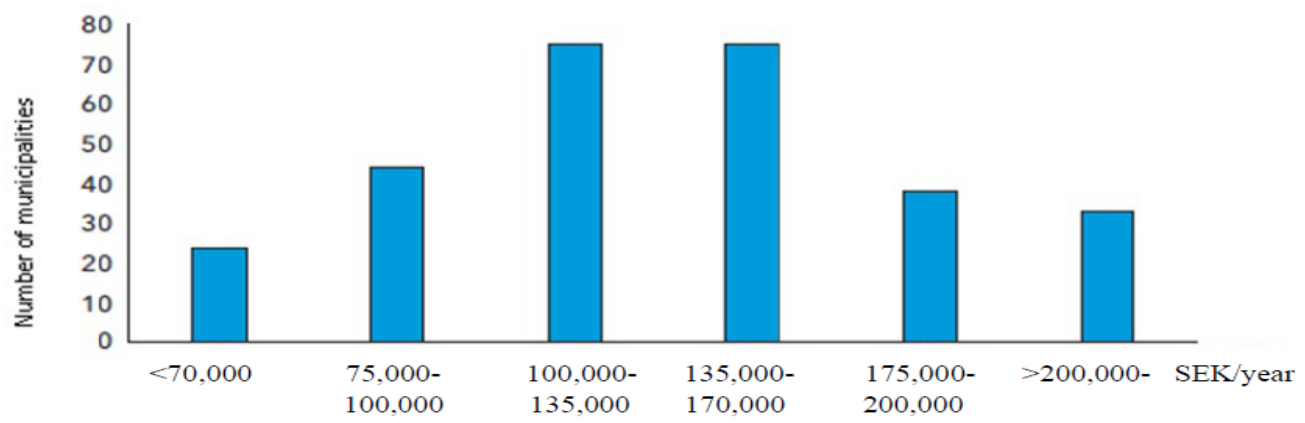

Figure 7. Spread in connection-fee costs between municipalities in Sweden [36].

Table 6 also shows that the connection fee in the Växö municipality increased by $10 \%$ every year since 2011, except for a 26\% increase in 2013-2014. According to Pehr Andersson, the cause of these sharp increases in connection fees is that the responsibility for the management of the connection costs gradually moved from the Department of Land and Development in the Växjö municipality to the W and WS department. With that scheme, the focus became to obtain all the real costs of W and WS installation within the new construction areas. Then, it turned out that the connection fee was too low to entirely cover the costs, a discrepancy which was then gradually corrected. Therefore, the fee increased, which had nothing to do with the Bergaåsen WTP.

The total price of the Bergaåsen project was 450 million SEK, as was mentioned before, and, as was made clear above, this significant investment did not cause an immediate increase in water fees for users in the Växjö municipality. Pehr Andersson stated that the explanation for this phenomenon is that a well-deliberated financial plan was applied in the project to avoid a shocking increase in W and WS fees. The plan was for the fee to begin to increase by $4 \%$ in addition to inflation for five years in a row when the project was already under the decision-making process. Eighty million kronor could thus be saved. The Alvesta municipality paid a connection-fee sum of 40 million SEK. In total, 120 million of the total 450 million SEK was then put in a fund for investment with the shortest depreciation period. Another factor that had a positive effect on keeping down the costs of the project was market interest rates, which gradually dropped to below $2 \%$; they were $7-8 \%$ during the calculation of the project. This downturn reduced annual costs by up to 20 million SEK.

\subsubsection{Quality Assurance and Evaluation}

The objectives of W and WS organizations should reflect the delivery of both the security and good quality of drinking water. One of the essential aspects that measures these criteria is subscribers' complaints. However, regarding drinking water from Bergaåsen, Pehr Andersson stated that during 2018, there were five-to-six complaints about brown water. Such complaints often happen because of something coming loose in the pipeline, and this has nothing with the quality of the water itself. 
There were complaints several/day with previous WTP, and these complaints were also of a completely different type, often for odor, taste, and bacteria, and many concerns because it was unpleasant.

In Sweden, chlorine is used in small amounts as a disinfectant in the production of drinking water within all WTPs based on surface water, but in only half the WTPs based on groundwater. The growth potential of bacteria is high in surface water because of the high content of organic matter and high temperatures, especially in the summer [3].

Pehr Andersson declared in an autumn 2009 interview, after starting the Bergaåsen project, that there was no chlorine in Växjö's tap water.

Even if W and WS authorities can end up with chlorination in WTP itself (through long-term filtration or UV radiation), they cannot guarantee that drinking water in the foreseeable future would reach consumers free of bacteria [37] because of the remainder of organic content after treatment in the WTP, the water temperature in the summer, and the age and deferred maintenance of the water supply network [38].

How should the Växjö municipality manage the risk of bacterial growth in the network without using chlorine? Pehr Andersson stated that there was no bacterial growth in the pipelines because of clean groundwater with less organic content compared to surface water, and the low water, temperature, which is less than $12{ }^{\circ} \mathrm{C}$ in the summer. Temperature with the previous WTP was $24^{\circ} \mathrm{C}$ in the summer. Growth potential is therefore completely different. However, because of the vulnerability of not using chlorine in the system as a safety measure, mainly when repairing pipelines, Steve Karlsson stated that some other measures have been introduced. For example, arranging courses in hygiene for pipe workers and dividing work assignments between the pipe workers so that a water worker only works with water facilities and wastewater workers only works with wastewater facilities. Nevertheless, there are complete facilities for chlorination both in Alvesta and in Växjö. They are monitored with an abundance of chlorine, and they can be immediately used if something happens.

The quality of incoming and outgoing drinking water from the Bergaåsen project is represented in Table 8.

Table 8. Water quality values for incoming and outgoing water for the future water supply (FWS) at Bergaåsen (the Växjö municipality, October 2018 interview).

\begin{tabular}{cccc}
\hline Parameters & Incoming Water & Outgoing Water & Limit Value Acc. NFA \\
\hline $\mathrm{Fe}(\mathrm{mg} / \mathrm{L})$ & 0.2 & $<0.03$ & $<0.10$ \\
$\mathrm{Mn}(\mathrm{mg} / \mathrm{L})$ & 0.28 & $<0.035$ & $<0.050$ \\
$\mathrm{Mg}(\mathrm{mg} / \mathrm{L})$ & 5.5 & 5.5 & 30 \\
$\mathrm{HCO} 3(\mathrm{mg} / \mathrm{L})$ alkalinity & 39 & 73 & $>60$ \\
$\mathrm{pH}$ & 6.6 & 8 & $7.5-9.0$ \\
$\mathrm{dH}$ & 3 & 3 & \\
Turbidity & 2 & $<0.10$ & 0.5 \\
Color & $<5$ & $<5$ & 15 \\
Calicium $(\mathrm{mg} / \mathrm{L})$ & 12 & 12 & $20-60$ \\
\hline
\end{tabular}

As seen in Table 8, water quality is excellent, and almost all parameters are within the accepted limits within very good margins. However, the level of calcium is only slightly under the limit value, and the reason for this, Pehr Andersson explained, is the lime-carbonic acid content. However, there are two different schools of thought in Sweden, and the consultants who work with the WTP in the Växjö municipality belong to one that argues that a range of $20-60 \mathrm{mg} / \mathrm{L}$ is for corrosion and does not affect health — they argue that such health concerns are exaggerated; therefore, $12 \mathrm{mg} / \mathrm{L}$ was accepted due to Pehr Andersson.

\subsubsection{Lessons and Advice}

Based on what he has accomplished, Pehr Andersson has learned some lessons, and the advice that he would give managers within the W and WS field to start a long-term planning project are: 
First, tell politicians the truth about the current conditions of the facilities. They should make the decisions, as they are who meet voters. In the case of the Växjö municipality, they did what they should have. Second, managers should try to find consultants who can think of innovative and new ways for improvement. Third, managers should not try to save costs when it comes to improving quality and should aim for the best possible outcomes.

It is not economically sensible in the long-term to go for the lowest price on everything, stated Steve Karlsson. This could result in the repeated payment for the same job. He added that he had considerable benefits from the top quality of the WTP and the WWTP that Pehr Andersson built. It is not more expensive to build with good quality; it may initially cost a little more, but that cost is made up for through future benefits, added Steve Karlsson.

The Bergaåsen project has been in operation for about ten years. In hindsight, what would Pehr Andersson want to do more for better WTPs? He explained that they might have built it with artificial-infiltration facilities from the beginning if they had better finances to guarantee increased capacity. The project is operating very well today, but they realize that they must supplement within a few years to cope. If they had known this from the beginning, it would have been possible to supply half a million people with drinking water from Bergaåsen, i.e., they should have gotten more capacity. However, what they have today is better in terms of quality, emphasized Pehr Andersson.

Moreover, both Steve Karlsson and Pehr Andersson confirmed that they would probably make the same decisions today that Pehr Andersson had made ten years ago, i.e., choosing groundwater from Bergaåsen for the FWS of the Växjö municipality.

\section{Conclusions}

This study aimed to analyze the entire process of developing the FWS of the Växjö municipality as a case study to show how strategies could be developed and applied to meet sustainability requirements in long-term planning, to inspire other municipalities to develop their long-term strategies, and to show how a FWS project ensures water quality and quantity after ten years of operation. The economic impact on the residents was also evaluated. The results of the case study also included advice and lessons to be learned.

The project of Bergaåsen, the FWS of the Växjö municipality, was put into operation in 2009. Extensive semi-structured interviews with two key persons, namely the previous and current manager of the W and WS department, were performed to describe how the FWS was implemented. The research questions that guided the study were: (1) What was the driving force for building a new WTP, i.e., the Bergaåsen project? (2) What was the entire process from planning to implementation? (3) How was the project technically built to ensure the desired quality and quantity, and how did it function? (4) What was the economic impact on the residents?

The driving forces for initiating the FWS project were: (1) The poor condition of the previous WTP and several daily complaints from users about poor water quality; these helped bring the problem to politicians and raised awareness of the need to invest. (2) The employment of a new manager with good experience for the department of the W and WS. (3) Giving him the green light to improve the situation at virtually any price. This reflects that organizations with political influence and active ownership had a significant role in launching with an excellent start. Moreover, the W and WS sector in the Växjö municipality has no intention of changing their type of organization into another. This study shows that, in line with some previous studies [5,39], this type of organization is suitable for long-term planning. The study is also in line with [4], which stated that active ownership could create conditions for long-term sustainable responsibility on its own by employing strategically competent staff.

The study found that the role of the manager was significant and evident throughout the whole process, (1) starting from investigating and evaluating seven different alternatives within an area of 80-100 km around the center of Växjö; (2) choosing Bergaåsen, which was based on the result from all surveys, test pumping, and the groundwater model to simulate the flow and level variation at different apportions of abstraction and infiltration; and (3) investment in quality and innovative technology so 
that Bergaåsen became the first fully computerized gravel formation in Sweden, which means that groundwater level could be seen online, and the amount of water in the magazine could be controlled.

Regarding ensuring the quantity of supplied water in the long term, the results confirmed that the water supply from Bergaåsen is satisfactory both now and in the long term, and it is in line with forecasts made in 1999-2001. It was then designed for 30 years, but via planned measures, an extension of the withdrawal capacity for a 50-year perspective became possible. Dividing the area of Bergaåsen into several zones was one of these measures-there are zones for raw water abstraction and for managing aquifer recharge, and two zones are kept as future reserve areas for the production of drinking water. Moreover, inducing water from Lagan River to the groundwater was applied from the beginning to guarantee the quantity of supplied water in the long term. Since the forecast was made, about 20 years have passed, and if the project handles supply for 10-30 more years, then all expectations will have been achieved.

Results of the collected data from interviews, document analysis, and the sustainability index indicate that expectations will be achieved, even though the forecast was made for the expected population by 2030 , which was $62,000-72,000$ people. Now, in mid-2019, the number people who are supplied from Bergaåsen is already more than 83,000.

One of the essential criteria that measure the delivery security and good quality of drinking water are the number of complaints from users. There were only five-to-six complaints in 2018, and they were about brown water, which had nothing to do with the quality of the water but with corrosion residuals that had come loose in the pipeline. However, the water quality is good, and almost all parameters are under the accepted limits with very good margins. Moreover, there is no chlorine in the drinking water of Växjö because there is no bacterial growth in the pipelines due to less organic content and a low water temperature. The choice not to chlorinate in Bergaåsen was mainly based on the experiences that exist in Sweden that biologically stable water is gained after the infiltration of water through gravel formation.

The results of the SI survey for the Växjö municipality for parameters that deal with drinking water showed that "safe healthy water," "security of delivery," and "satisfied customers" had a green color for all the years that Växjö participated in the survey. Thus, results show (see Table 1) that over $90 \%$ of water users were satisfied, and less than $3 \%$ were dissatisfied.

The economic impact on water users can be explained by analyzing the rate of increases in the fees paid for water consumption before the start of Bergaåsen until now. In general, water fees are composed of two parts: Consumption fees, and connection fees. However, this study showed that the rate of increase in the fixed portion of the consumption fees from 2008 to 2018 was 3.5\% per year. This rate is a marginal and mostly due to inflation [33] Meanwhile, the price of water consumption dropped from $10.25 \mathrm{SEK} / \mathrm{m}^{3}$ in 2008 to $9.6 \mathrm{SEK} / \mathrm{m}^{3}$ in 2018. (see Table 3). Thus, even the average of annual consumption fee in the Växjö municipality for a typical type A house was $8 \%$ less than the average of the annual consumption fee for Swedish municipalities in 2018 for the same house type, as Tables 4 and 5 show $[35,36]$.

Concerning the connection fees, the results showed that they have increased by $10 \%$ every year since 2011 except for a 26\% increase in 2013-2014 (see Table 6). According to Pehr Andersson 2018, this was because of some organizational changes 2013 in the Växjö municipality and the fact that the connection fees were then too low to entirely cover the costs of W and WS installation. These were then gradually corrected, and this had nothing to do with the Bergaåsen WTP.

Thus, investment impact of the Bergaåsen project did not cause an immediate increase in water fees for users for a few reasons. First, because of the particular financial plan that was applied, through which 120 million of the total 450 million SEK was secured and put in a fund for investment with the shortest depreciation period.

The second factor that had a positive effect on keeping the costs of the project down was market interest rates, which gradually dropped to below $2 \%$. They were $7 \%-8 \%$ during the calculation of the project. 
The lessons and advice from Pehr Andersson that should be considered by managers when driving their organization forward are: (1) Tell politicians how bad the situation is and let them make decisions, as they are who meet voters; (2) it is essential that managers try to find internal and external experts who can think and act in new and innovative ways; and (3) they should not save on quality, instead aiming for as good a result as possible. Steve Karlsson admitted that he had considerable benefits from the top-quality WTP and the WWTP built by Pehr Andersson.

Two changes in the initial concept of processing technology that came about during these ten years of operation could also be considered as lessons. The first was discontinuing the use of $\mathrm{CO}_{2}$ and $\mathrm{CaCO}_{3}$ before re-infiltration. The second was replacing $\mathrm{CO}_{2}$ and $\mathrm{Na}_{2} \mathrm{CO}_{3}$ with $\mathrm{NaOH}$ tanks. They were initially chosen for adjusting the $\mathrm{pH}$ level and alkalinity in the clean water. These two changes were made because of problems caused by using $\mathrm{Na}_{2} \mathrm{CO}_{3}$ and $\mathrm{CaCO}_{3}$.

The Växjö municipality reflects an apparent ability to develop long-term strategies and plans through planning, processing, and implementing a project in this dimension, ensuring the future water supply in the Vaxjo and Alvesta municipalities.

In order to give a clearer picture of Växjö's ability in developing strategic plans and steering long-term sustainable municipal W and WS management, supplementary studies should be done. Further studies could include how Växjö handles other central issues, e.g., whether they have done or have plans to adapt the W and WS systems to future climate change or if they have plans to meet requirements for wastewater treatment from drug residues and sludge handling.

The SI reveals that the Swedish municipality reflects a picture of a short planning horizon for renewal of the pipeline network. To add new findings to similar studies in W and WS, further research on how municipalities cope with this central issue is also needed.

Author Contributions: N.N. designed, conducted, and performed the study; interpreted and analyzed the results; and wrote the paper. K.M.P. supervised the whole study, added some topics to the interview questions, contributed several valuable points of view and options, and supported the entire research process.

Funding: This research is funded by the Department of Construction Engineering and Lighting Science, School of Engineering, Jönköping University.

Acknowledgments: The authors wishes to thank the interviewees, who devoted time and contributed to what the study has achieved. The authors offers special thanks to the Department of Construction Engineering and Lighting Science, School of Engineering, Jönköping University for funding this study, the costs of language editing, and the costs that cover publication.

Conflicts of Interest: The authors declares no conflict of interest.

\section{References}

1. Söderqvist, T.; Lindhe, A.; Rosén, L.; Sjöstrand, K.; Bergion, V.; Soutukorva, Å. Dricksvattenutredningens preliminära förslag till åtgärder för trygg och säker dricksvattenförsörjning-Vilka är de samhällsekonomiska nyttorna och vad behövs för att dessa ska bli verklighet; DRICKS- Centrum för dricksvattenforskning, Institution för byggoch miljöteknik, Chalmers tekniska högskola: Göteborg, Sweden, 2016. (In Swedish)

2. Natur Vårds Verket \& Havs och Vattenmyndigheten. Vägledning för kommunal VA-planering för hållbar VA-försörjning och god vattenstatus; Havs och Vattenmyndigheten: Göteborg, Sweden, 2014. (In Swedish)

3. Svenskt Vatten. Fakta om Vatten, Produktion av Dricksvatten 2016 (Facts about Water, Production of Drinking Water). Available online: http://www.svensktvatten.se/fakta-om-vatten/dricksvattenfakta/produktion-avdricksvatten/ (accessed on 25 June 2018). (In Swedish).

4. Jonsson, R. Organisering och Styrning av Kommunal VA-Verksamhet-En Studie av Förmågor, Brister och Förbättringspotential (Organization and Control of Municipal Water Activities-A Study of Abilities, Shortcomings and Potential for Improvement); Svenskt Vatten AB: Bromma, Sweden, 2017.

5. Glaas, E.; Hjerpe, M.; Jonsson, R. Conditions Influencing Municipal Strategy-Making for Sustainable Urban Water Management: Assessment of Three Swedish Municipalities. Water 2018, 10, 1102. [CrossRef]

6. Salomonsson, M.; Larsson, M.; Karlsson, S.; Alexandersson, H.; Andreasson, M. Beredskapsplanering för Skyfall (Preparedness Planning for Heavy Rain). 2017. Available online: http://www.svensktvatten.se/ contentassets/9fda8707312944ba8968f374e54c418a/svu-rapport_2017-03.pdf (accessed on 19 February 2019). 
7. Sörelius, H.; Svensson, G. Användning av hållbarhetsindex för effektive samverkan mellan kommuner (Use of Sustainability Index for Effective Collaboration between Municipalities); Svenskt Vatten AB: Bromma, Sweden, 2016.

8. Svenskt Vatten. Resultatrapport för Hållbarhetsindex 2017 (Result Report for Sustainability Index 2017). Available online: https://www.svensktvatten.se (accessed on 23 March 2018). (In Swedish)

9. Al-Najjar, N. Framtida Vattenförsörjning för Växjö Kommun-Bedömning av Olika Alternatives (The Future Water Supply of Växjö Municipality_Evaluation of Different Alternatives). Vatten 2007, 63, 299-311.

10. Najar, N. Water Management and Performance on Local and Global Scales-A Comparison between Two Regions and Their Possibilities of Knowledge Transfer. Licentiate Thesis, Royal Institute of Technology, Stockholm, Sweden, 2010.

11. Barends, E.; Rousseau, D.M.; Briner, R.B. Evidence-Based Management. In the Basic Principles; The Center for Evidence-Based Management: Amsterdam, The Netherlands, 2014.

12. Directive 2000/60/EC of the European Parliament and of the Council of 23 October 2000 Establishing a Framework for Community Action Water Policy Area. Available online: https://eur-lex.europa.eu/legalcontent/EN/TXT/?uri=LEGISSUM:128002b (accessed on 10 February 2018).

13. Andersson, M. Planera för Dricksvatten-vårt Viktigaste Livsmedel (Plan for Drinking Water-Our Most Important Food); Tryck KPH- Trycksakbolaget: Uppsala, Sweden, 2014.

14. Länsstyrelse. Vattenförsörjningsplan för Kronobergs län, Kommun översikt, Meddelande nr 2012-17 (Water Supply Plan for Kronoberg County: Municipal Overview). 2012. Available online: https://www. lansstyrelsen.se/kronoberg/stat-och-kommun/miljo/vatten/regional-vattenforsorjningsplan (accessed on 11 June 2018). (In Swedish)

15. Länsstyrelsen. Kronobergs Länsförfattningssamling- Kungörelse om Fastställelse av Vattenskyddsområde med Skyddsföreskrifter för Växjö Kommuns Grundvattentäkt på Bergaåsen i Ljungby Kommun. 07FS 2009:50. pdf (Water Protection Area for Bergaåsen in Ljungby Municipality, Kronoberg County Council's Constitution, County Administrative Board, 07FS 2009:50). Available online: https://www.lansstyrelsen.se/kronoberg (accessed on 12 September 2018). (In Swedish).

16. Havs och Vattenmyndighet. Havs och Vattenmyndighetens beslut om utpekande av områden av riksintresse för anläggningar för vattenförsörining- Bergaåsens dricksvattenanläggningar 2016 (Sea and the Water Authority's decision on the designation of areas of national interest for the facilities of water supply-Bergaås drinking water). Handläggare, Margareta Lundin Unger, Enheten för miljöprövning och miljötillsyn Dnr 2841-2016. Available online: https://www.havochvatten.se (accessed on 12 September 2018). (In Swedish).

17. Malm, A.; Svensson, G.; Bondeblind, M.; Balmer, P. Prioriterade Nyckeltal för VA-Verksamhet (Priority Key Figures for Water-Activity); Svenskt Vatten AB: Bromma, Sweden, 2018. (In Swedish)

18. Växjö Kommun. (Växjö, Sweden). 2015. Unpublished work.

19. Växjö Kommun. (Växjö, Sweden). 2016. Unpublished work.

20. Växjö Kommun. (Växjö, Sweden). 2017. Unpublished work.

21. Växjö Kommun. (Växjö, Sweden). 2018. Unpublished work.

22. Statistiska centralbyrån. SCB:S Medborgarundersöking Våren- 2012 Växjö kommun, Rapport (SCB:S Citizens' Survey); SCB: Stockholm, Sweden, 2012; pp. 41-44.

23. Statistiska centralbyrån. SCB:S Medborgarundersöking 2018 Växjö kommun, Rapport (SCB:S Citizens' Survey 2018 Växjö municipality, Raport). Available online: https://www.scb.se/hitta-statistik (accessed on 21 February 2019). (In Swedish)

24. Växjö kommun. Budget 2019 (PDF). Med Verksamhetsplan för 2020 och 2021. Växjö Municipality budget 2019 with Business Plan for 2020 and 2021 (pdf). Available online: https://vaxjo.se (accessed on 15 December 2018). (In Swedish).

25. Alvesta 2018 Fakta om Alvesta kommun nov 2018 (Facts about Alvesta Municipality Nov 2018). Available online: http://www.alvesta.se/om-kommunen/Om-Alvesta-Kommun/ (accessed on 15 December 2018). (In Swedish).

26. VAI VA-Projekt AB and Mark \&Vatten Ingenjörerna AB. (Växjö, Sweden). 2001. Unpublished work.

27. Thomasson, A. Organisering för ökad uthållighet-En studie av olika organisations formar inom den svenska VA-sektorn (Organization for Increased Endurance-A Study of Various Organizational Forms within the Swedish Water and Wastewater Sector); Svenskt Vatten AB: Bromma, Sweden, 2013. 
28. Anell, A.; Mattisson, O. Samverkan I kommuner och landsting_En kunskapsöversikt; Student Litteratur: Lund, Sweden, 2009.

29. Jonsson, R.; Jannesson, E. Social Investments: A Social Innovation Approach and the Importance of Active Ownership 2014. Available online: http://urn.kb.se/resolve?urn:nbn:se:liu:diva-112598 (accessed on 15 March 2019).

30. Växjö Kommun. Taxa för Växjö Kommuns Allmänna Vatten-och Avloppsanläggningar (Water and Wastewater Charges for Växjö Municipality) 2018. Available online: https://www.expansiva.vaxjo.se/sidor/jobb-ochforetag/hallbarhet-och-miljo/vatten-och-avlopp/taxa-for-vatten-och-avlopp.html (accessed on 27 May 2019).

31. Växjö kommun. Taxa för Växjö kommuns allmänna vatten-och avloppsanläggningar (Water and Wastewater Charges for Växjö Municipality); Växjö Municipality: Växjö, Sweden, 2008.

32. Växjö Kommun. Taxa för Växjö Kommuns Allmänna Vatten-och Avloppsanläggning (Water and Wastewater Charges for Växjö Municipality) 2017. Available online: http://docplayer.se/106145587-Taxa-for-vaxjokommun-allmanna-vatten-och-avloppsanläggning-ar-2017.html. (accessed on 10 February 2019).

33. Statistiska centralbyrån. SCB: Konsumentprisindex (Consumer Price Index, CPI) 2018. Available online: https://www.scb.se/hitta-statistik/statistik- (accessed on 20 March 2019).

34. Svenskt Vatten. Taxeundersökning- Svenskt Vatten Statistik över VA-taxor (-Statistics on Water Tariffs-Swedish Water and WasteWater Association) 2008. Available online: http://www.svensktvatten.se/ vattentjanster/organisation-och-juridik/va-statistik/taxeundersokning/ (accessed on 20 March 2019).

35. Svenskt Vatten. Taxestatistik 2011, 2012, 2013, 2014, 2015, 2016, 2017 och 2018. Available online: http: //www.svensktvatten.se/vattentjanster/organisation-och-juridik/va-statistik/taxeundersokning/ (accessed on 20 March 2019).

36. Svenskt Vatten. Kommentar till 2018 års Taxestatistik (Comments on the 2018 Charge statistics); Svenskt Vatten distribution: Motala, Sweden, 2018.

37. Säve-Söderbergh, M.; Malm, A.; Dryselius, R.; Toljander, J. Mikrobiologiska risker vid dricksvattendistribution, Svenskt Vatten Rapport Nr 19. 2013. Available online: http://www.svensktvatten.se/Documents/Kategorier/ Dricksvatten/Rapporter/2013-19\%20Livsmedelsverket_mikrobiologiska\%20risker\%20vid\%20distribution. pdf (accessed on 20 May 2018).

38. Svenskt Vatten. Förnyelseplanering av VA-nät-Bedömning av långsiktiga behov och stöd vid prioritering-Sammanfattning av rapporterna 2011-12, 13 och 14. (Renewal Planning of VA Networks-Assessment of Long-Term Needs and Support in Prioritization-Summary of Reports 2011-12, 13 and 14); Svenskt Vatten AB: Bromma, Sweden, 2014. (In Swedish)

39. Pahl-Wostl, C. An evolutionary perspective om water governance: From understanding to transformation. Water Resour. Manag. 2017, 31, 2917-2932. 